\title{
The Effect of Enriched Learning Environments on the Conceptual Understanding of Students: "The Erosion and Landslide"1
}

\author{
Tülay Şenel Çoruhlu ${ }^{1}$, Arzu Kirman Bilgin ${ }^{2}$, Sibel Er Nas ${ }^{1}$ \\ ${ }^{1}$ Karadeniz Technical University, Fatih Faculty of Education, Trabzon, Turkey \\ ${ }^{2}$ Kafkas University, Faculty of Education, Kars, Turkey \\ Correspondence: Tülay Şenel Çoruhlu, Karadeniz Technical University, Fatih Faculty of Education, Trabzon, Turkey.
}

Received: July 28, $2016 \quad$ Accepted: August 16, $2016 \quad$ Online Published: September 22, 2016

doi:10.11114/jets.v4i10.1892 URL: http://dx.doi.org/10.11114/jets.v4i10.1892

\begin{abstract}
The aim of this research is to investigate the effect of enriched learning environments which have been developed in the framework of the "erosion and landslide" concepts on the conceptual understanding of students. A quasi-experimental method has been used in this research. The sample consists of 40 students. 5th grade students (aged 11-12) selected from a primary school in the province of Trabzon in Turkey. To collect data, the researchers used concept test, interview consisting of semi-structured questions and drawing test. When the post test results are examined, a significant difference is identified in favour of the experiment group $(\mathrm{U}=128,00, \mathrm{p}<.05)$. However, the fact that students were not able to reflect this result to their drawings is striking. In the post drawings made on the concepts of erosion and landslide, the number of students who did not make any drawings in the experiment and control groups is quite high. This result can be stem from student's operational periods. 5th graders are in the process of transition from the concrete operational period to the abstract operational period. They had problems to reflect their thinking's to drawings. Ready-made pictures were utilized in the poster assignment used in this research. A poster activity which includes the drawings of students can be carried out in a future research.
\end{abstract}

Keywords: conceptual understanding, enriched learning environment, erosion, landslide

\section{Introduction}

The "Earth Summit" was held for the first time in June 1992 in the city of Rio de Janerio of Brazil. The fact that damages humankind has caused in the air, soil and water ecosystems with the increase of the world population must not be disregarded was emphasized in the symposium. The obligation to combat against the damages humankind has caused to ecosystems was adopted by all world countries at the end of the symposium. The combat against the damages to ecosystems has been ongoing rapidly since 1992 to this day. As of 1995, 17th of June is celebrated as the "World Day to Combat Desertification" by the United Nations. The World Day to Combat Desertification draws attention to the protection and sustainable management of soil. Moreover, the vital importance of soil has been emphasized and actions to be taken to prevent further damages to it have been elaborated with the United Nations' declaration of 2015 as "International Year of Soils".

Erosion and landslide are effective factors in the destruction of soil. Erosion is a common ecological problem for many countries. In Europe, about 114 million ha, or more than 17\% of the total land area are affected by soil erosion (Gobin, Gavers, Jones, Kirkby \& Kosmas, 2003). Soil erosion emerges as a great threat in the production capacity increase of agriculture (Montgomery, 2007). In Turkey, the yield obtained from agricultural lands and soil has been decreasing and desertification has been increasing particularly in recent years. There are nongovernmental organizations in our country which have been established with the purpose of combating against erosion. One of these organizations is the "Turkish Foundation for Combating Erosion, for Reforestation and the Protection of Natural Habitats (TEMA)" founded in 1992. Despite the existence of various non-governmental organizations in the combat against erosion in our country, there is no organization founded directly with the purpose of combating against landslide. TEMA indirectly contributes to the prevention of landslide with the activities it carries out. Numerous foundations or organizations worldwide are working

\footnotetext{
${ }^{1}$ This study has been produced from the data obtained in the framework of the project with code 12462 supported by the Karadeniz Technical University, Scientific Research Project (BAP).
} 
on finding solutions to the effects of erosion and landslide and awareness-raising on both national and international levels. One of the most effective ways of raising-awareness among people is educational institutions. If students understand what the phenomena of erosion and landslide are and know how to combat these national processes, successful results can be obtained for the sustainability of ecosystems. The concepts of erosion and landslide are addressed in the science programs, on the elementary school 5th grade level in our country. These concepts are also included in the scope of the social sciences programs. The increase in the scientific literacy of students on what the erosion and landslide concepts included in the science program are, how they occur and how to combat them is of utmost importance.

\subsection{Students Understanding of the Erosion and Landslide}

However, examining the existing literature, it has been observed that students are not able to explain the concepts of erosion and/or landslide and they have alternative concepts on these concepts (Alım, Özdemir \& Y1lar 2008; Ateş, 2013; Bozkurt, Akın \& Uşak 2004; Martinez, Bannan \& Kitsantas, 2012; Pinar, Dikmenli \& Buldur, 2000; Özgen, 2013). Bozkurt, et all (2004) have identified the alternative concepts of 6th, 7th and 8th graders on erosion. In this research, it has been concluded that students confuse the concept of erosion with other concepts such as landslide and earthquake, also they are incompletely informed on the concept of erosion. In a research they carried out on 5th graders, Alım, et all (2008) have identified "erosion" to be the concept on which the understanding levels of students are the lowest. Moreover, they have established that students are not able to explain the difference between erosion and landslide clearly. Ateş (2013) has researched the misconceptions high school students have on the concept of erosion. As a result of the research, he has reached the conclusion that more than half of the students explain erosion as landslide. Özgen (2013) has identified confusion of erosion with landslide among teacher candidates as well. Biriş̧̧i \& Metin (2010) have developed concept cartoons to be used in the teaching of the erosion concept within the 5E instructional model. As a conclusion of the research, they have emphasized the necessity of carrying out applied activities as well as developing materials. Students are not able to clearly define how erosion and/or landslide occur, confuse the definition of erosion with earthquake and landslide, are misinformed or partially informed about the factors causing erosion and/or landslide, are not able to comprehend the relationship between soil structure and soil (Bozkurt, et all, 2004; Gaither, 2008; Pinar et all, 2000). Students' alternative thoughts about the concepts of erosion and landslide and the insufficiency of applied activities aimed towards eliminating these alternative thoughts (Birişçi \& Metin, 2010) bring the necessity of the ongoing activity into the forefront again. Therefore, this research is thought to contribute to the elimination of the alternative concepts students have about the concepts of erosion and landslide. Furthermore, it is believed that this research will be a pioneer in the development of awareness on the prevention of ecosystem damage by ensuring the literacy of students on combatting erosion and landslide. In the scope of the research, enriched learning environments were presented to students in the teaching of the erosion and landslide concepts. Learning environments were enriched with conceptual change text, poster preparation activities and case studies created by utilizing daily life problems.

Conceptual change text helps students to overcome their misconceptions (Chambers \& Andre, 1997; Guzzetti, Snyder, Glass \& Gamas, 1993; Hynd, McWhorter, Phares \& Suttles, 1994; Kim \& Van Dunsen, 1998), understand complex scientific concepts and provide meaningful learning (Duit, 1991). This text illustrates inconsistencies between the misconceptions and scientific knowledge (Kim \& Van Dunsen, 1998) by using explanations and examples. Discussing the ideas after reading the conceptual change text had better effect on conceptual understanding (Alverman \& Hynd, 1989). There have been numerous studies that have investigated the positive effects of conceptual change texts on students' understanding of concepts and misconceptions, also promote meaningful learning in different areas (Al khawaldeh \& Al Olaimat 2010; Balci, Cakiroglu \& Tekkaya, 2006; Beerenwinkel, Parchmann \& Gräsel, 2011; Chambers \& Andre, 1997; Çalık, Ayas \& Coll, 2007; Çil, 2014; Özmen, 2007; Özkan \& Sezgin Selçuk, 2015). The authors used conceptual change text because of time efficient and facilitate meaningful learning in this research. The fact that students have alternative thoughts due to confusing the erosion and landslide concepts with one another has been identified in various studies (Alım et all, 2013; Ateş, 2013; Pınar et all, 2000; Bozkurt et all, 2004; Gaither, 2008; Özgen, 2013). With the conceptual change text utilized in the scope of the research, the interchange of students' alternative concepts with scientific facts has been aimed.

Posters are two-dimensional graphics that presents detailed information about subjects or represent students' performance. Posters carry caricatures, pictures, diagrams, tables and experiments which arouse students' interest. Students understand concepts in detailed with posters (Huddle, 2000; Mulnix \& Penhale, 1997). Posters improved students' discussion and communication skills (Billington, 1997; Bracher Centrell \& Wilkie, 1998; Hay \& Thomas, 1999; Hunter, 1997; Mulnix \& Penhale, 1997). Also, poster presentation makes learning environment more fun (Dunstan \& Bassinger, 1997). Posters increase students' success rate (Arslan, Keskin \& Doğan Bora, 2005). The authors used poster to design entertainment learning environment, provide the learners opportunities to construct their knowledge. In the scope of this research, students were asked in groups to prepare posters which reveal the differences 
between erosion and landslide. The collaboration of students in groups is thought to contribute to their peer learning. Demonstration of how erosion and landslide occur in the selection process of students on the pictures they would use in posters has been aimed.

Case study contributes to the meaningful learning of students through their confrontation with real life problems. Case studies are presented with text in this research. This text helps in the relating of school knowledge with real life (Dori, Tal \& Tsaushu, 2003). Case study texts are known to develop the problem solving, concluding by analysis and decision-making skills of students (Merseth, 1991; Hartfield 2010), provided meaningful learning (Dori \& Herscovitz, 2005; Dori \& Sasson, 2008; Dori, Tal \& Tsaushu, 2003). Woolfolk (1998) emphasized the importance of using the case study in bridging the gap between abstract subjects and real life. Moreover, Mayoh and Kunutton (1997) have stated that teachers do not attach sufficient importance to the transfer of scientific concepts received at school to daily life. Case study text ranks among the methods which can be used for relating to daily life in learning environments. Two case texts have been utilized in the scope of this research. The case study of "A Black Sea Village in Van" and "Yusuf tries to understand the concepts of erosion and landslide" include slices from daily life. 5E instructional model is used in the research.

\subsection{E Instructional Model}

According to constructivist learning theory, students do not adopt other people's thoughts and understanding. Students create their own by comparing new experiences with their own previous experiences and understanding through active engagement in their learning process. Students are given an opportunity to connect the information and ideas in constructivist learning theory (Coll \& Taylor, 2001; Hand \& Treagust, 1991; Matthews, 2002; Geelan, 1995; Saunders, 1992; Shiland, 1999). This approach has a positive effect on learners' academic success, retention and attitude scores (Semerci \& Batdi, 2015). Grounded on the constructivist learning theory, $5 \mathrm{E}$ instructional model includes higher order thinking skills. According to Bybee (1993; 1997), the 5E instructional model are listed as Engagement (each topic begins with a lesson that mentally engages students with an activity or question), Exploration (students carry out hands-on activities in which they can explore the concept or skill), Explanation (students explain scientifically the results obtained from their observations and experience), Elaboration (students are allowed to apply learned information to new situations. This is a good time for students to practice their new knowledge), Evaluation (the phase provides an opportunity for students to review and reflect on their own learning and new understanding and skills).

The aim of this research is to investigate the effect of enriched learning environments which have been developed in the framework of the "erosion and landslide" on the conceptual understanding of students.

\section{Method}

As the measurement of the effect of enriched learning environment on students' conceptual understanding within concepts on "erosion-landslide". A quasi-experimental method ("pre-test-post-test" with control group) has been used in this research. The groups were established through a non-random selection during the formation of sample (Tharenou, Donohue \& Cooper, 2007). Groups were composed as experiment and control groups through equitable assignment way in quasi-experimental method (Büyüköztürk, 2004). Therefore, educational research mostly prefer quasi-experimental method that are an alternative to full experimental design (Çepni, 2010). Thus, quasi-experimental method was adopted in this research.

\subsection{Sample}

The sample of the research consisted of 40 students. One control group (with 20 students -11 girls and 9 boys, their mean age: 11.74) and one experimental group (with 20 students -12 girls and 8 boys, their mean age: 12.06). Two voluntery teachers in the same school participated in the research. The teachers graduated from Karadeniz Technical University. The experimental group teacher had 6 years experience and the control group teacher had 10 years of experience. Intervention materials which used in the experiment group was introduced to the teacher by the researchers before the intervention.

\subsection{Data Collection Tools}

To collect data, the researchers used concept test, interview consisting of semi-structured questions and drawing test. Concept test including two open-ended questions. These questions are; "What does the concept of erosion mean to you? How would you describe this concept? Please explain" and "What does the concept of landslide mean to you? How would you describe this concept? Please explain".

The interviews including semi-structured questions. The aim of the interviews to investigate the effectiveness of the materials on the conceptual understanding of students. Volunteery students were selected in this process. Interviews conducted with 10 of the experiment group students (E2, E3, E6, E8, E10, E13, E14, E16, E17, E19). The same questions using in the concept test was used in this research. 
Drawings makes very few restriction on the responses of students (White \& Gunstone, 1992). Therefore, besides concept test, drawing test was used in this research. The questions students were asked are as follows:

1-What does the erosion evoke in your mind? Please show by drawing.

2-What does the landslide evoke in your mind? Please show by drawing.

Concept and drawing test were administered one week before the intervention as a pre-test to experiment and control groups. The same tests were employed as a post-test immediately after the intervention to these groups. To enhance content and face validity the tests was evaluated by one science educators and two science teachers. To measure reliability of the concept and drawing tests, they were implemented 12 grade 6 students, who learned these concepts at 5 th grade. Semi-structured interview questions were administered one week before the intervention as a pre interview to 10 of the experiment group students. The same questions were employed as a post interview immediately after the intervention. Questions were evaluated by one science educator and one science teacher to enhance validity. To measure reliability of the semi-structured questions, it was implemented 2 grade 6 students. Interviews were recorded. Each interviews were approximately took 7-10 minutes.

\subsection{Data Analysis}

Marek's (1986) categorization used in the analysis of the concept test and interviews. Following criteria; Complete Understanding (Code A) (3 points), Partial Understanding (Code B) (2 points), Alternative Concept (Code C) (1 point), No response or Irrelevant Responses (Code D) (zero point) was utilized. Mann-Whitney U-test was used to compaire the experiment and control groups points. Three categories was used in analysis of drawing test. Correct drawing, incorrect drawing and no answer categories have been presented as a table including frequency values. Also, samples from student drawings have been presented with tables. Students were coded in line with research ethic. For instance, student number 5 from the experiment group has been shown as $\mathrm{E} 5_{\mathrm{PT}}$ in the pre-test and as $\mathrm{E} 5_{\mathrm{LT}}$ in the post test. Student number 2 from the control group has been coded similarly as $\mathrm{C} 2_{\mathrm{PT}}$ and $\mathrm{C} 2_{\mathrm{LT}}$.

\subsection{Intervention}

In this research materials using in the experiment group were prepared according to the constructivist learning approach. 5E (Entering/Engagement, Examining, Explaining, Elaborating and Evaluating) instructional model was taking into consideration. The reason behind using the $5 \mathrm{E}$ instructional model in the scope of the research is related to the fact that $5 \mathrm{E}$ model is question-based and has been identified to provide positive contributions to the learning and conceptual change of students (Carreno, 2004; Goldston, Day, Sundberg \& Dantzler, 2010; Wilder \& Shuttleworth, 2004; Orgill \& Thomas, 2007; Clark, 2003; Özsevgeç, 2006; Anil \& Batdi, 2015). The intervention process was consisted of 6 classes of 40 minutes. The intervention in the experiment group has been presented in Table 1.

Table 1. Now we will summarize teaching design, which took six class-hour session

\begin{tabular}{ll}
\hline Entering & At this stage; the teacher asked the first question on the conceptual change text (Appendix 1). Activity to elicit \\
students' preexisting knowledge: "What is erosion in your opinion?" Since students pre existing knowledge \\
was activated, teachers didn't interfere with students' ideas.
\end{tabular}


As it can be seen in Table 2, there is no significant difference between the pre-test scores of the concept test implemented on the experiment and control group $(U=187,00, p>.05)$. There is a significant difference in favour of the experiment group between the post test scores implemented on experiment and control groups $(U=128,00, p<.05)$. Data collected from question 1 (concept test) which is related to the concept of erosion has been presented in Table 3 .

Table 3. Frequency distribution of the answers given to question 1 and example statements

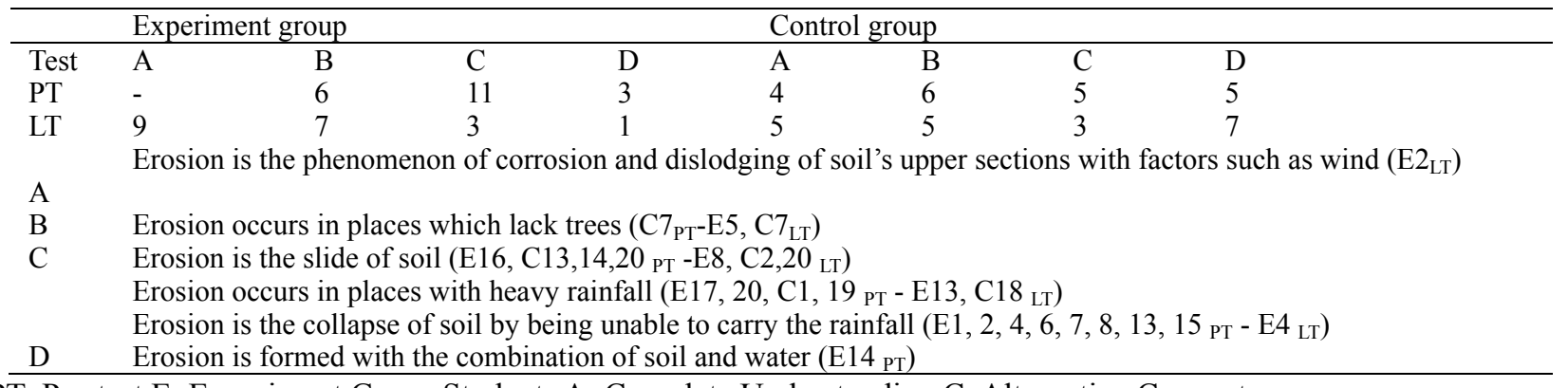

PT: Pre-test E: Experiment Group Students A: Complete Understanding C: Alternative Concept

LT: Post-test C: Control Group Students B: Partial Understanding D: No or Irrevelant Answer

When Table 3 is examined, it is observed that identified alternative concepts emerge in the "Erosion is the slide of soil", "Erosion occurs in places with heavy rainfall" and "Erosion is the collapse of soil by being unable to carry the rainfall" codes. Data collected from question 2 which is related to the concept of landslide has been presented in Table 4.

Table 4. Frequency distribution of the answers given to question 2 and example statements

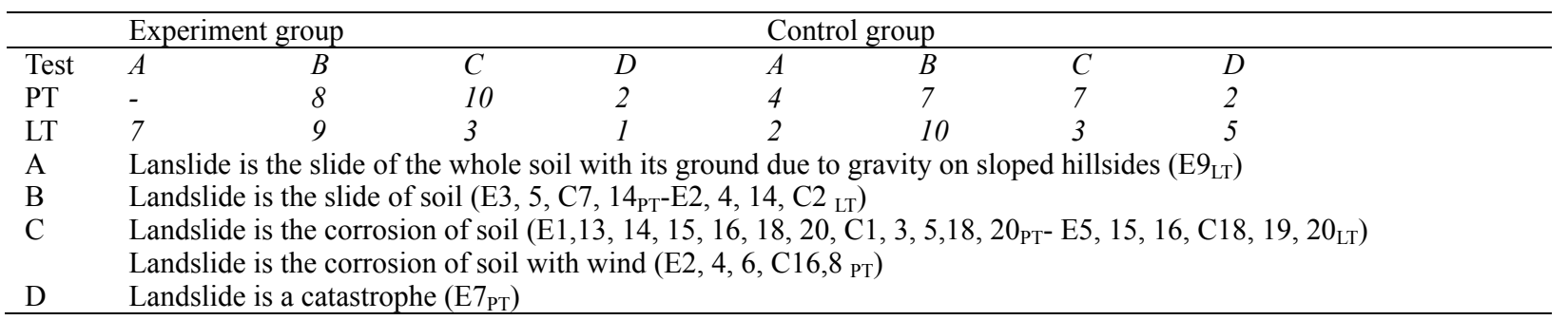

When Table 4 is examined, it is observed that identified alternative concepts emerge in the "Landslide is the corrosion of soil" and "Landslide is the corrosion of soil with wind" codes. Findings obtained from the student drawing test have been presented below. Frequencies of the data obtained from question 1 and 2 which are related to the erosion and landslide concepts have been presented in Table 5 .

Table 5. Frequencies and categories of the findings obtained from the drawing test

\begin{tabular}{|c|c|c|c|c|c|c|c|c|}
\hline \multirow[b]{4}{*}{ Categories } & \multicolumn{4}{|c|}{ Erosion } & \multicolumn{4}{|c|}{ Landslide } \\
\hline & \multirow{2}{*}{\multicolumn{2}{|c|}{$\begin{array}{l}\text { Experiment } \\
\text { Group }\end{array}$}} & \multirow{2}{*}{\multicolumn{2}{|c|}{ Control Group }} & \multirow{2}{*}{\multicolumn{2}{|c|}{$\begin{array}{l}\text { Experiment } \\
\text { Group }\end{array}$}} & \multirow{2}{*}{\multicolumn{2}{|c|}{ Control Group }} \\
\hline & & & & & & & & \\
\hline & PT (f) & LT (f) & PT (f) & LT (f) & PT (f) & LT (f) & PT (f) & LT (f) \\
\hline Corrosion of soil & 5 & 9 & 5 & 5 & 4 & - & 5 & 4 \\
\hline Slide of soil & 5 & - & 6 & 1 & 7 & 9 & 5 & 7 \\
\hline No Drawing & 10 & 11 & 9 & 14 & 9 & 11 & 10 & 9 \\
\hline
\end{tabular}

When the preliminary drawing results of the groups are examined, it is observed that students who did not make drawings on either concepts are in the majority. Whereas the majority of students who made drawings, made incorrect drawings for both concepts. When the post test results are examined, the number of students in the experiment group who made correct drawings for the erosion concept is 9 while this number is 5 for the control group. The number of experiment group students who made correct drawings for the landslide concept is 9 while this number is 7 for the control group. It is important to point out that the number of students who preferred not to make a drawing in the post test for the experiment and control groups is high like in the pre-test. Samples of the student drawings included in the correct and incorrect drawing category related to the concepts of erosion and landslide have been presented in table 6 . 
Table 6. Samples of the student drawings which belong to the correct and incorrect drawing categories relate to erosion and landslide

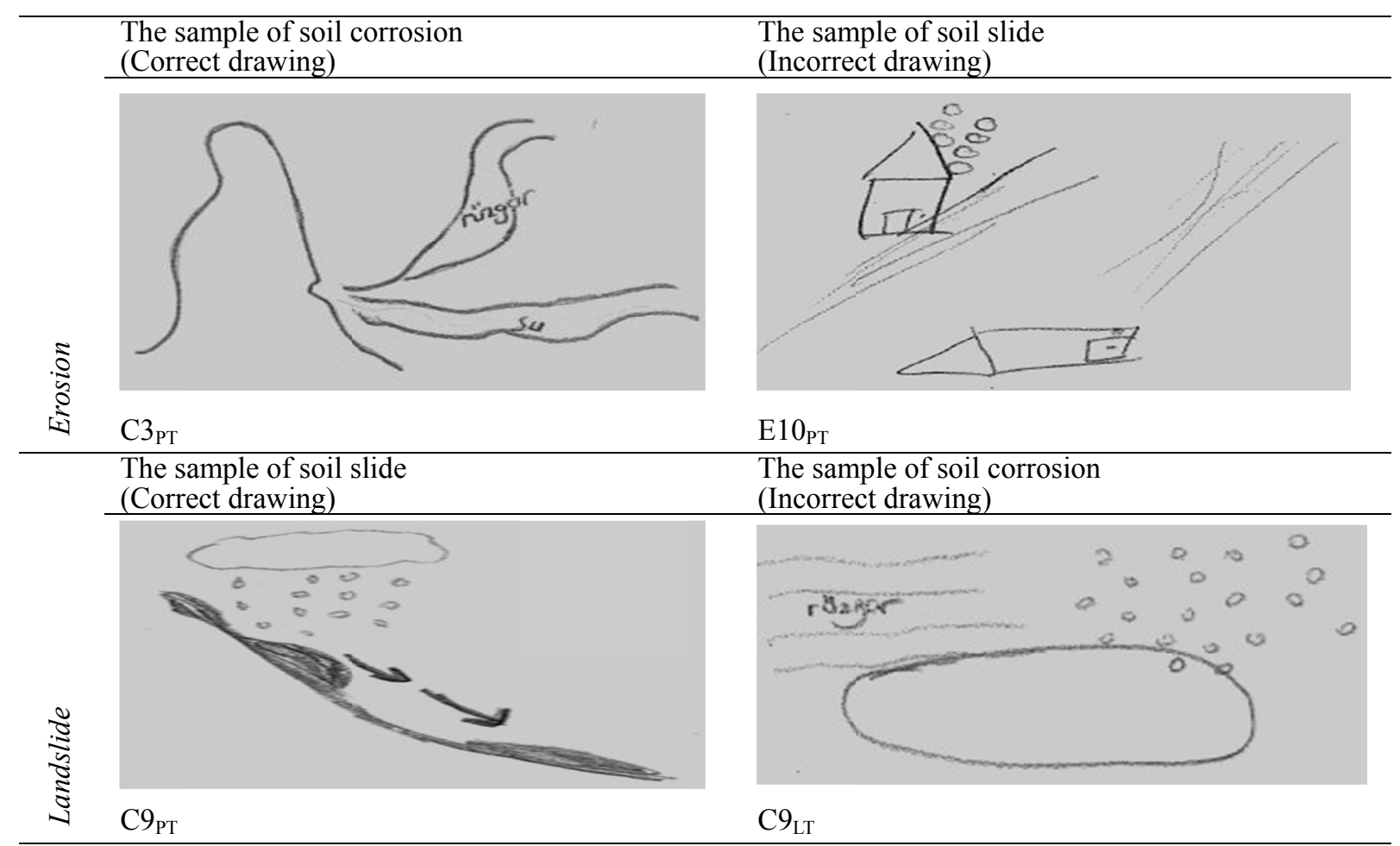

Findings obtained from question 1 which is related to the concept of erosion have been presented in Table 7 .

Table 7. Categorization of the answers given to the first interview question and example statements

\begin{tabular}{cl}
\hline C. & \multicolumn{1}{c}{ Example statements } \\
\hline$A$ & $\begin{array}{l}\text { Erosion is the corrosion and transfer of the soil's most fertile upper section to other } \\
\text { places due to factors such as rain, flood and wind. Erosion occurs in a long time } \\
\left(E 3,17_{\mathrm{PI}^{-}} \mathrm{E} 2,3,6,17_{\mathrm{LI}}\right) .\end{array}$ \\
$B$ & $\begin{array}{l}\text { Erosion is the corrosion of soil }\left(E 8,10,13,14,16,19_{\mathrm{LI}}\right) . \\
C\end{array}$ \\
& $\begin{array}{l}\text { Erosion is the collapse of soil by being unable to carry the rainfall }\left(E 2,6,13,14_{\mathrm{PI}}\right) . \\
\text { Erosion is the slide of soil }\left(E 8,10,16_{\mathrm{PI}}\right) .\end{array}$ \\
$D$ & Erosion is a catastrophe $\left(\mathrm{E} 19_{\mathrm{PI}}\right)$.
\end{tabular}

PI: Pre-Interview, LI: Post-Interview

When Table 7 is examined, it is observed that there has been an increase in the number of students answering in the "complete and partial understanding" categories after the enriched learning environment. The findings obtained from the 2 nd interview question related to the concept of landslide are presented in the Table 8 below.

Table 8. Categorization of the answers given to the second interview question and example statements

\begin{tabular}{cl}
\hline C. & \multicolumn{1}{c}{ Example statements } \\
\hline & Landslide is the sliding of whole soil with its ground. Landslide occurs on hillsides \\
$A$ & with high slopes due to gravity. $\left(\mathrm{E} 3,13_{\mathrm{P}^{-}} E 2,3,6,8,10,17_{\mathrm{LI}}\right)$ \\
$B$ & Landslide is the slide of soil $\left(E 2,10,17_{\mathrm{PI}^{-}} E 13,14,16,19_{\mathrm{LI}}\right)$ \\
$C$ & Landslide is the corrosion and transfer of the soil $\left(E 6,8,14,16,19_{\mathrm{PI}}\right)$ \\
\hline
\end{tabular}

When the answers students gave to the related question are examined, it is observed that there has been an increase in the number of students answering in the "complete and partial understanding" categories in post interviews compared to pre interviews. The emergence of the alternative concepts identified in preliminary interviews is not observed in post interviews.

\section{Discussion and Conclusions}

The results obtained from the concept test, drawing test and interview questions have been discussed in light of the literature and their conclusions have been presented.

When the pre-test results of experiment and control group students are examined, it is observed that the prior knowledge of students in both groups on the subject is close to one another $(\mathrm{U}=187,00, \mathrm{p}>.05)$. When the post test results are examined, however, a significant difference is identified in favour of the experiment group $(\mathrm{U}=128,00, \mathrm{p}<.05)$. This 
may arise from the enriched learning environment used in the 5E model. The activities of case study, conceptual change text, posters were utilized in the teaching material used in the experiment group. Erosion and landslide confront us as big problems in our country just like in the whole world. The Black Sea Region where the study was carried out is one of the regions landslide occurs the most in Turkey. Teaching of erosion and landslide by presenting cases from daily life can be stated to be effective. The case studies of "A Black Sea Village in Van" and "Yusuf tries to understand the concepts of erosion and landslide" are thought to have contributed to students' relating of school knowledge with real life knowledge. Hence, Woolfolk (1998) has stated that case study method can be utilized in bridging the gap between abstract subjects and real life. Campbell and Lubnen (2000) emphasized that students better structured concepts in their minds if they relate events with daily life.

Conceptual change text persuaded students to see the difference of erosion to landslide and how the phenomena of erosion-landslide occur scientifically. When the existing literature is examined, there are various studies which have discovered that conceptual change texts are effective in the elimination of students' incorrect thoughts (Balc1 et all, 2006; Beerenwinkel et all, 2011; Chambers \& Andre, 1997; Çalık, Ayas \& Coll, 2007; Çil, 2014; Özkan \& Sezgin Selçuk, 2015; Özmen, 2007). Also Çalık, Ayas and Coll (2007) found that pre-service elementary trainees' alternative conceptions relate to solution chemistry are changed to become more in accord with the scientific view after the intervention of the conceptual change text.

Students were firstly informed about what erosion and landslide are and how they occur by reviewing the literature with posters. They worked together as a group in the selection of pictures to be glued to the posters and consulted with one another on how these phenomena occur. There are studies in the literature which were carried out to establish the effect of the poster technique on the increase of students' conceptual learnings and/or success (Arslan et all, 2005; Huddle, 2000; Mulnix \& Penhale, 1997). When the post test data is examined, it is observed that the experiment group is more successful than the control group. When the teaching conducted in the control group is examined, only the activity of "What Has Happened to Our Soil?" (Bayram \& Kibar, 2014) has been included on the effect of erosion. It is observed that the information is presented to students more theoretically in the treatment process of the subject and the activitiy examples in the book which establish the differences between erosion and landslide are insufficient. Therefore, conceptual understanding of the students in the control group can be stated to be at a lower level. Ural Keleş (2009) stated that course books which were previously used in our country were also insufficient in terms of ensuring conceptual change. This conclusion demonstrates the importance of the course books' inclusion of enriched learning environments.

When Table 2 is examined, majority of experiment and control students are observed to have alternative concepts about erosion in the pre-test. The alternative concepts expressed among students are the statements of "Erosion is the collapse of soil by being unable to carry the rainfall", "Erosion is the slide of soil" and "Erosion occurs in places with heavy rainfall". When these thoughts of students are examined, it is observed that they have confused the concept of erosion with landslide (Alım, et all, 2013; Bozkurt, et all, 2004; Gaither, 2008; Ateş, 2013; Özgen, 2013; Pınar, et all, 2000). The most frequently expressed alternative understanding among students is the statement of "Erosion is the collapse of soil by being unable to carry the rainfall". Landslide occurs due the collapse of soil which is unable to carry the rainfall after heavy precipitation. Students confuse the occurrence type of landslide with the occurrence type of erosion. In a similar vein, Martinez, et all (2012) have identified the misconception that erosion occurs only due to rainfall as a result of their study. When Table 3 is examined, majority of experiment and control students are observed to have alternative concepts about landslide in the pre-test. The alternative thoughts of "Landslide is the corrosion of soil" and "Landslide is the corrosion of soil with wind" have been identified among students.

These alternative concepts identified in students have also been reflected in student drawings. While the number of students who drew erosion as landslide in the pre-test is 5 in the experiment group, this number is 6 in the control group. In Table 6, the student with code $\mathrm{E} 10_{\mathrm{PT}}$ drew a house in the drawing he/she made in the pre-test and showed that the house changed place by sliding with the soil as a result of erosion. Students' matching of the erosion concept with the landslide concept is an indicator of how important daily life experiences are in the teaching of concepts. The research was carried out in the Trabzon province of Turkey. The Trabzon province is among the provinces where landslide occurs the most in Turkey. As the concepts of erosion and landslide are frequently used interchangeably among the public, students may confused these concepts with one another as well. Non-scientific explanations which are used among the public are known to be effective in creating alternative concepts in students (Kortz \& Murray, 2009). Therefore, it is important for teachers to present concepts to students by relating the daily life language with scientific language (Dove, 1997; King, Bellocchi \& Ritchie, 2008; Torres-Guzman \& Howes, 2009; Whitelegg \& Parry, 1999).

When the concept test and interview data of students (table 3, 4, 7,8) are examined, students are observed to have given answers in the complete and partial understanding category after the intervention. However, the fact that students were not able to reflect this to their drawings is striking. In the post drawings made on the concepts of erosion and landslide, 
the number of students who did not make any drawings in the experiment and control groups is quite high. Drawing is a technique which ensures the discovery of dimensions which cannot be discovered with open-ended and other understanding research techniques (White \& Gunstone, 1992). Drawings are very valuable as they provide more detailed information beyond words. However, the fact that elementary school 5 th graders are in the process of transition from the concrete operational period to the abstract operational period can be considered as the reason behind the difference between the data obtained from the interview and drawing questions.

\section{Recommendations}

Research results have demonstrated that the enriched learning environment which has been developed has a positive effect in the learning of the erosion and landslide concepts. The alternative concepts which were identified in experiment group students are observed to have been eliminated after teaching. However, students have not been able to reflect what they have learned to their drawings. Therefore, drawing activities which address the differences between the concepts of erosion and landslide can be included in the enriched learning environment which has been developed. For instance, ready-made pictures were utilized in the poster activity used in this research. A poster activity which includes the drawings of students can be carried out in a future research. In assessment activities, photographs taken from different regions can be included and whether they are erosion or landslide can be discussed.

\section{References}

Al khawaldeh, S., \& Al Olaimat, A. (2010). The contribution of conceptual change text accompanied by concept mapping to eleventh-grade students' understanding of cellular respiration concepts. Journal of Science Education and Technology, 19, 115-125. http://dx.doi.org/10.1007/sl 0956-009-9 185-z

Alım, M., Özdemir, Ü., \& Yılar, B. (2008). 5. sınıf öğrencilerinin bazı coğrafya kavramlarını anlama düzeyleri ve kavram yanılgıları [The Perceptions Levels of the Geography Concepts and The Misconception of the 5th Year Students]. Atatürk University Journal of Graduate School of Social Sciences, 11, 151-162.

Alvermann D. E., \& Hynd, C. (1989). Effects of prior knowledge activation modes and text structure of nonscience majors' comprehension of physics. Journal of Educational Research, 83, 97-102. http://dx.doi.org/10.1080/00220671.1989.10885937

Anil, Ö., \& Batdi, V. (2015). A comparative meta-analysis of 5E and traditional approaches in Turkey. Journal of Education and Training Studies, 3(6), 212-219. http://dx.doi.org/10.11114/jets.v3i6.1038

Arslan, O., Keskin, N., \& Doğan, B. N. (2005). Alternatif bir öğrenme aracı: Poster sunumu ödevi [An alternative learning style: Poster presantation]. Journal of National Education, 33, 168.

Ateş, M. (2013). A research on high school students' concepts of "erosion" by using phenomenographic analysis. Educational Research and Reviews, 8(9), 449-453. http://dx.doi.org/10.5897/ERR2013.1425

Balci, S., Cakiroglu, J., \& Tekkaya, C. (2006). Engagement, exploration, explanation, extension, and evaluation (5E) learning cycle and conceptual change text as learning tools. Biochemistry and Molecular Biology Education, 34, 199-203. http://dx.doi.org/10.1002/bmb.2006.49403403199

Bayram, G., \& Kibar, F. S. (2014). Ortaokul Fen Bilimleri 5 Ders Kitabı [Elementary Science 5th Textbook]. Ankara: Sevgi Publishing, Retrieved from http://www.eba.gov.tr/ekitapdetay/2608 (31.07.2015)

Beerenwinkel, A., Parchmann, I., \& Gräsel, C. (2011). Conceptual change texts in chemistry teaching: a study on the particle model of matter. International Journal of Science and Mathematics Education, 9, 1235-1259. http://dx.doi.org/10.1007/s10763-010-9257-9

Billington, H. L. (1997). Poster presentation and peer assessment: Novel forms of evaluation and assessment. Journal of Biological Education, 31, 218-220. http://dx.doi.org/10.1080/00219266.1997.9655566.

Birişçı, S., \& Metin, M. (2010). Developing an instructional material using a concept cartoon adapted to the 5E model: A sample of teaching erosion. Asia-Pacific Forum on Science Learning and Teaching, 11(1), 1-16.

Bozkurt, O., Akın, S. B. \& Uşak, M. (2004). İlköğretim 6., 7. ve 8. sınıf öğrencilerinin "erozyon" hakkındaki ön bilgilerinin ve kavram yanılgılarının tespiti [Identifying of grade 6, 7. and 8. students' pre-informations and misconceptions about the erosion]. Journal of Kırşehir Education Faculty, 5(2), 277-285.

Bracher, L., Centrell, J., \& Wilkie, K. (1998). The process of poster presentation: A valuable learning experience. Medical Teacher, 20, 552-557. http://dx.doi.org/10.1080/01421599880274

Büyüköztürk, Ş. (2004). Sosyal bilimler için veri analizi el kitabı [Data analysis handbook for social sciences]. Ankara: PegemA Publication. 
Bybee, R. (1993). Instructional model for science education, in developing biological literacy. Colorado Springs, CO: Biological Sciences Curriculum Studies.

Bybee, R. W. (1997). Improving instruction. in achieving scientific literacy: From purposes to practice. Portsmouth, Nh: Heinemann.

Çalık, M., Ayas, A., \& Coll, R. (2007). Enhancing pre-service elementary teachers' conceptual understanding of solution chemistry with conceptual change text. International Journal of Science and Mathematics Education, 5, 1-28. http://dx.doi.org/10.1007/s10763-005-9016-5

Campbell, B., \& Lubben, F. (2000). Learning science through contexts: helping pupils make sense of everday situations. International Journal of Science Education, 22(3), 239-252. http://dx.doi.org/10.1080/095006900289859

Carreno, B. B. (2004). Facilitating with “eeee's. Strides toward a Land Ethic, 9.

Çepni, S. (2010). Araştırma ve proje çalışmalarına girişs [Introduction to research and project studies]. Trabzon, Celepler Printing.

Chambers, K. S., \& Andre, T. (1997). Gender, prior knowledge, interest and experience in electricity and conceptual change text manipulations in learning about direct current. Journal of Research in Sience Teaching, 34(2), 107-123. http://dx.doi.org/10.1002/(SICI)1098-2736(199702)34:2<107::AID-TEA2>3.0.CO;2-X

Çil, E. (2014). Teachıng nature of science through conceptual change approach: Conceptual change texts and concept cartoons. Journal of Baltic Science Education, 13(3), 339-350.

Clark, I. (2003). Soils ain’t soils. Investigating Australian Primary \& Junior Science Journal, 19, 13-16.

Coll, R. K., \& Taylor, T. G. N. (2001). Using constructivism to inform tertiary chemistry pedagogy. Chemistry Education: Research and Practice in Europe, 2(3), 215-226. http://dx.doi.org/10.1039/B1RP90024B

Dori Y. J., \& Herscovitz, O. (2005). Case-based long-term professional development of science teachers. International Journal of Science Education, 27(12), 1413-1446. http://dx.doi.org/10.1080/09500690500102946

Dori Y. J., \& Sasson, I. (2008). Chemical Understanding and Graphing Skills in an Honors Casebased Computerized Chemistry Laboratory Environment: The Value of Bidirectional Visual and Textual Representations. Journal of Research in Science Teaching, 45, 219-250. http://dx.doi.org/10.1002/tea.20197

Dori, Y. J., Tal, R. T., \& Tsaushu, M. (2003). Learning and assessing biotechnology topics through case studies with built-in dilemmas. Science Education, 87, 767-793.

Dove, J. (1997). Student ideas about weathering and erosion. International Journal of Science Education, 19(8), 971-980. http://dx.doi.org/10.1080/0950069970190809

Duit, R. (1991). On the role of analogies and metaphores in learning science. Science Education, 75(6), 649-672. http://dx.doi.org/10.1002/sce.3730750606

Dunstan, M. \& Bassinger, P. (1997). An innovative model: Undergraduate poster sessions by health professional majors as a method for communicating chemistry in context. Journal of Chemical Education, 74(9), 1067-1068. http://dx.doi.org/10.1021/ed074p1067

Gaither, F. J. (2008). Common misconceptions about weathering, erosion, volcanoes and earthquakes. An online magazine for k-5 teachers, Retrieved from

http://beyondpenguins.ehe.osu.edu/issue/earths-changing-surface/common-misconceptions-about-weathering-erosi on-volcanoes-and-earthquakes

Geelan, D. R. (1995). Matrix technique: A constructivist approach to curriculum development in science. Australian Science Teachers Journal, 41(3), 32-37.

Gobin, A., Gavers, G., Jones, R., Kirkby, M., \& Kosmas, C. (2003). Assessment and reporting on soil erosion. (Technical Report No: 94). Copenhagen: European Environment Agency.

Goldston, M. J., Day, J. B., Sundberg, C., \& Dantzler, J. (2010). Psychometric analysis of a 5E learning cycle lesson plan assessment instrument. International Journal of Science and Mathematics Education, 8(4), 633-648. http://dx.doi.org/10.1007/s10763-009-9178-7

Guzetti, B. J., Snyder, T. E., Glass, G. V., \& Gamas, W. S. (1993). Promoting conceptual change in science. A comparative meta-analysis of instructional interventions from reading education and science education. Reading Research Quarterly, 28(2), 117-159. http://www.jstor.org/stable/747886

Hand, B., \& Treagust, D. F. (1991). Student achievement and science curriculum development using a constructive 
framework. School Science and Mathematics, 91(4), 172-176. http://dx.doi.org/10.1111/j.1949-8594.1991.tb12073.x

Hartfield, P. J. (2010). Reinforcing constructivist teaching in advanced level biochemistry through the introduction of case-based learning activities. Journal of Learning Design, 3(3), 20-31.

Hay, I., \& Thomas, S. M. (1999). Making sense with posters in biological science education. Journal of Biological Education, 33(4), 209-214. http://dx.doi.org/10.1080/00219266.1999.9655668

Huddle, P. A. (2000). A poster session in organic chemistry that markedly enhanced student learning. Journal of Chemical Education, 77(9), 1154-1157. http://dx.doi.org/10.1021/ed077p1154

Hunter, K. A. (1997). Poster presentations an alternative to the traditional classroom lecture. American Journal of Pharmaceutical Education, 61(1), 78-80.

Hynd, C. R., Mc Wharter, J. Y., Phares, U. L., \& Suttles, C. W. (1994). The role of instructional variables in conceptual change in high school physics topics. Journal of Research in Science Teaching, 31(9), 933-946. http://dx.doi.org/10.1002/tea.3660310908

Kim, S., \& Van Dunsen, L. M. (1998). The role of prior knowledge and elaboration in text comprehension and memory: a comparison of self-generated and text provided elaboration. American Journal of Psychology, 111, 353-378.

King, D., Bellocchi, A., \& Ritchie, S. M. (2008). Making connections: Learning and teaching chemistry in context. Research in Science Education, 38(3), 365-384. http://dx.doi.org/10.1007/s11165-007-9070-9

Kortz, K. M., \& Murray, D. P. (2009). Barriers to college students learning how rocks form. Journal of Geoscience Education, 57(4), 300-315. http://dx.doi.org/10.5408/1.3544282

Marek, E. A. (1986). They misunderstand, But they'll pass. The Science Teacher, 53(9), 32-35.

Martinez, P., Bannan, B., \& Kitsantas, A. (2012). Bilingual students' ideas and conceptual change about slow geomorphological changes caused by water. Journal of Geoscience Education, 60(1), 54-66.

Matthews, M. R. (2002). Constructivism and Science Educations: A Further Appraisal. Journal of Science Education and Technology, 11(2), 121-134. http://dx.doi.org/10.1023/A:1014661312550

Mayoh, K., \& Knutton, S. (1997). Using out of school experience in science lesson: reality or rhetoric? International Journal of Science Education, 19, 849-867. http://dx.doi.org/10.1080/0950069970190708

Merseth, K. K. (1991). The early history of case-based instruction: Insights for teacher education today. Journal of Teacher Education, 42(4), 243-249. http://dx.doi.org/10.1177/002248719104200402

Montgomery, D. (2007). Soil erosion and agricultural sustainability. Proceedings of the National Academy of Sciences of the United States, 104, 13268-13272.

Mulnix, A., \& Penhale, S. J. (1997). Modelling the activities of scientists: A literature review and poster presentation assignments. The American Biology Teacher, 59(8), 482-487. http://dx.doi.org/10.2307/4450362

Orgill, M., \& Thomas, M. (2007). Analogies and the 5E model. The Science Teacher, 74(1), 40- 45.

Özgen, N. (2013). Öğretmen adaylarının erozyon kavramına yönelik algıları: Fenomonografik bir araştırma [Perception of preservice teachers regarding the concept of erosion: A phenomenographic study]. Hacettepe Univeristy Journal of Education, 28, 321-334.

Özkan, G., \& Sezgin, S. G. (2015). The effectiveness of conceptual change texts and context-based learning on students' conceptual achievement, Journal of Baltic Science Education, 14(6), 753-763.

Özmen, H. (2007). The effectiveness of conceptual change texts in remediating high school students' alternative conceptions concerning chemical equilibrium. Asia Pacific Education Review, 8(3), 413-425.

Özsevgeç, T. (2006). Determining effectiveness of guided materials about force and motion unit based on the 5E model for elementary students. Journal of Turkish Science Education, 3(2), 36-48.

Pınar, A., Dikmenli, M., \& Buldur, A. (2000). Erozyon kavramı üzerine öğrenci görüşleri [Students' ideas on the concept of erosion]. S.U. Educational Faculty Journal of Social Sciences, 9, 1-9.

Saunders, W. L. (1992). The constructivism perspective: implications and teaching strategies for science. School Science and Mathematics, 92(3), 136-141. http://dx.doi.org/10.1111/j.1949-8594.1992.tb12159.x

Semerci, Ç., \& Batdi, V. (2015). A meta-analysis of constructivist learning approach on learners' academic achievements, retention and attitudes, Journal of Education and Training Studies, 3(2). 171-180. http://dx.doi.org/10.11114/jets.v3i2.644 
Shiland, T. W. (1999). Constructivism: The implications for laboratory work. Journal of Chemical Education, 76(1), 107-109. http://dx.doi.org/10.1021/ed076p107

Tharenou, P., Donohue, R., \& Cooper, B. (2007). Management Research Methods. New York: Cambridge University Press.

Torres-Guzman, M. E., \& Howes, E. V. (2009). Experimenting in teams and tongues: Team teaching a bilingual science education course. In K. Richardson Bruna, \& K. Gomez (Eds.), The work of language in multicultural classrooms: Talking science, writing science (pp. 317-339). New York: Routledge.

Ural, K. P. (2009). Kavramsal Değişim Metinleri, Oyun ve Drama ile Zenginleştirilmiş 5 E Modelinin Etkililiğinin Belirlenmesi: "Canlıları Sinfflandıralım" Örneği [Determining effectiveness of guided materials based on 5E model enriched with conceptual change texts, games and drama: A sample of classification of living thing] (Unpublished doctoral dissertation). Karadeniz Technical University, Trabzon.

White, R. T., \& Gunstone, R. F. (1992). Probing understanding. Hong Kong: Graphicraftltd.

Whitelegg, E., \& Parry, M. (1999). Real-life contexts for learning physics: meanings, issues and practice. Physics Education, 34(2), 68-72.

Wilder, M., \& Shuttleworth, P. (2004). Cell inquiry: A 5E learning cycle lesson. Science Activities, 41, $25-37$. http://dx.doi.org/10.3200/SATS.41.4.37-43

Woolfolk, A. E. (1998). Educational psychology. Boston: Allyn and Bacon. 


\section{Appendix}

Appendix 1. Conceptual Change Text

\section{What is erosion in your opinion?}

Students;

Think that erosion is landslide.

Let's correct the misconceptions you have with facts.

The student conception stated above is scientifically wrong. Because soil sliding is landslide. Landslide is the sliding of whole soil with its ground. Landslide occurs on hillsides with high slopes due to gravity. Whereas erosion is the corrosion and transfer of the soil's most fertile upper section to other places due to factors such as rain, flood and wind. While erosion occurs in a long time interval, landslide is instantaneous. While landslide occurs more frequently in case of heavy rainfall, no heavy rainfall is needed for erosion. Erosion is more frequent in lands which are arid and lack plant cover. Landslide is more frequent in the Black Sea Region due to its reception more rainfall and sloped lands. We can say that erosion is more frequent in interior zones.

Now we have learned better that erosion is not landslide.

\section{Appendix 2. My Erosion and Landslide Poster}

\section{My Erosion and Landslide Poster Subject:}

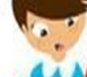

Mist

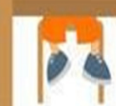

Let's prepare a poster which shows how erosion and landslide occur, what kind of differences exist between erosion and landslide.

Poster Preparation Directive: Prepare the poster activity by working with your group mates. Execute division of labour among group members in this process.

Tools-materials: Backdrop cardboard in the size of $50-70 \mathrm{~cm}$, glue, information and pictures collected on erosion and landslide, newspaper reports, pencil, A4paper.

The poster you prepare must contain the answers to the following questions about erosion and landslide:

What is erosion and how does it occur?

What is landslide and how does it occur?

What are the differences between erosion and landslide?

What should be done to prevent erosion and landslide?

\section{Following the steps below will be useful to you in the poster preparation phase}

1.First of all, gather all the pictures and information you have collected about Erosion and Landslide together.

2.Determine the information you think should be included in the poster according to the preparation purpose of the poster.

3.Decide on the pictures and texts you think should be included in the poster.

4.Prepare a draft of your poster on the cardboard and check it. Change the places of texts and pictures you think are not neat or not situated in the correct place.

5.Present the posters you have prepared to the class in order with the guidance of your teacher. The poster you have prepared will be assessed according to the grading rubric below.

\section{Appendix 3. "A Black Sea Village in Van" case study}

\section{A Black Sea Village in Van}

A landslide occurred in the Çaykara county of Trabzon about 50 years ago. The landslide caused great damages in the county. Many families became homeless because of the landslide. Material and moral losses of people were huge. In response, the government at the time placed the landslide victims to the Dönerdere Village of the Özalp county which is located in the Iran border of the Van province. Landslide victims demonstrated the industriousness of people from the Black Sea Region. These people developed agriculture and animal husbandry in this 
village. They changed the atmosphere of the village by building houses with roofs. People from the Black Sea

Region continue their existence with the people of the region without any problems for almost half a century.

How does landslide occur in your opinion?

What kind of damages may the landslide have caused?

What kind of effects does landslide have on people's lives?

Appendix 4. Yusuf Tries to Understand the Concepts of Erosion and Landslide Case study

\section{Yusuf Tries to Understand the Concepts of Erosion and Landslide}

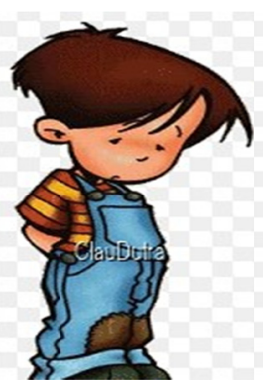

Yusuf is travelling to Trabzon with his family in the semester break. It is raining in Trabzon. While they are on their way to Trabzon, they see that the road is closed and vehicles are waiting in queues. When they get off the vehicle, they learn that landslide occurred and the road is closed because of it.

The road gets opened after waiting for a while. In the evening news, it is stated that the village road was closed due to landslide.

Yusuf asks his father "Dad, is landslide and erosion the same thing?". His father tells Yusuf that erosion and landslide is not the same thing. A landslide occurred today while

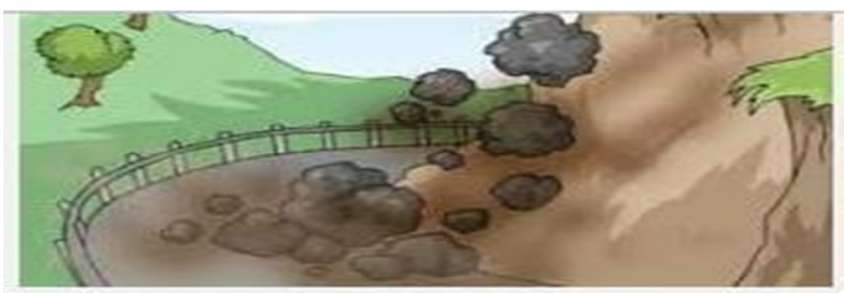

we were travelling. Landslide occurs in sloped areas with rainfall. Yusuf asks "So, what is erosion then?". His father states that erosion is more frequent in arid lands which lack plant cover. He also says erosion can occur not only with the effect of rainfall but also with different factors such as wind. Even though his father made an explanation, Yusuf wants to obtain more information by researching the differences between erosion and landslide.

How do you think Yusuf has answered the question below as a result of the research he conducted?

What are the similarities between the concepts of landslide and erosion?

What are the factors causing erosion and landslide in your opinion?

What can be done to prevent erosion and landslide in our country in your opinion?

\section{$(\mathrm{cc}) \mathrm{Br}$}

This work is licensed under a Creative Commons Attribution 3.0 License. 